\title{
Mortality, survival and prognostic factors of people with AIDS in intensive care unit
}

\author{
Mortalidade, sobrevida e fatores prognósticos de pessoas \\ com aids em unidade de terapia intensiva \\ Mortalidad, supervivencia y factores pronósticos de las personas \\ con SIDA en la unidad de cuidados intensivos
}

How to cite this article:

Cunha GH, Lima RCRO, Lopes MVO, Galvão MTG, Siqueira LR, Fontenele MSM. Mortality, survival and prognostic factors of people with AIDS in intensive care unit. Rev Esc Enferm USP. 2021;55:e20210121. DOI: https://doi.org/10.1590/1980-220X-REEUSP-2021-0121.

\author{
Gilmara Holanda da Cunha ${ }^{1}$ \\ Reângela Cíntia Rodrigues de \\ Oliveira Lima ${ }^{1}$
}

\section{Marcos Venícios de Oliveira Lopes ${ }^{1}$ \\ Marli Teresinha Gimeniz Galvão ${ }^{1}$ \\ Larissa Rodrigues Siqueira ${ }^{1}$ \\ Marina Soares Monteiro Fontenele ${ }^{1}$}

${ }^{1}$ Universidade Federal do Ceará, Departamento de Enfermagem, Programa de Pós-graduação em Enfermagem. Fortaleza, CE, Brazil.

\begin{abstract}
Objective: To analyze mortality, survival and prognostic factors of patients with AIDS in Intensive Care Unit (ICU). Method: Retrospective cohort study with a sample of 202 patients with AIDS in ICU, whose sociodemographic, epidemiological, and clinical characteristics were obtained from medical records and assessed. Results: Patients were mostly male (73.8\%) and drug users (59.4\%), with no regular health follow-up (61.4\%) and no adherence to antiretrovirals (40.6\%), presenting low CD4+ T lymphocyte count (94.0\%) and high viral load (44.6\%). The main causes of hospitalization were sepsis and respiratory and renal insufficiency. The mean duration of hospitalization was 11.9 days ( $\mathrm{p}=0.0001)$, with a $41.6 \%$ survival; $58.5 \%$ died in the ICU. Sepsis upon admission $(p<0.001)$, pressure injury $(p=0.038)$, sexual exposure $(\mathrm{p}=0.002)$, high viral load $(\mathrm{p}=0.00001)$ and prolonged hospitalization $(\mathrm{p}<0.001)$ increased the risk of death. Conclusion: Most patients had no regular health followup, were drug users and presented low CD4+ T lymphocyte count and high viral load. The high mortality indicated that antiretroviral adherence is essential to reduce viral resistance, opportunistic diseases, and mortality.
\end{abstract}

\section{DESCRIPTORS}

Acquired Immunodeficiency Syndrome; Mortality; Survival; Intensive Care Units. 


\section{INTRODUCTION}

AIDS is a serious public health problem because of its pandemic character and high morbidity and mortality ${ }^{(1)}$. Antiretroviral therapy (ART) has made infection a chronic health condition ${ }^{(2)}$, but challenges remain, including failures in ART adherence ${ }^{(3)}$, consequences of HIV infection in the long-term ${ }^{(4)}$ and adverse events of antiretrovirals ${ }^{(5)}$. In addition, many patients do not follow treatment measures because of their low socioeconomic status and level of schooling ${ }^{(6)}$. These factors contribute synergistically to the increase in HIV transmission and coinfections, which require hospital care and even intensive care ${ }^{(7-8)}$.

Before ART, people with AIDS were admitted to the intensive care unit (ICU) due to the consequences of immunosuppression ${ }^{(9)}$. Currently, in addition to opportunistic diseases, they are also hospitalized for conditions associated with aging and trauma due to accidents and violence ${ }^{(7-10)}$. These patients represent a challenge for the multidisciplinary health care team, due to the complexity of the care required ${ }^{(10)}$. Furthermore, studies show that knowledge about characteristics and clinical evolution of patients with AIDS in the ICU is limited ${ }^{(7-10)}$, leading to the need for research on factors that influence survival and mortality.

Since 2010, AIDS-related mortality has decreased by $34 \%$ due to access to ART, but this decrease has not occurred quickly enough, considering the 90-90-90 global target, that by $2020,90 \%$ of people with HIV would be diagnosed, $90 \%$ on ART and $90 \%$ with viral suppression ${ }^{(11)}$. In view of the above, studies that identify the factors that affect the diagnosis, treatment and retention of HIV infection are needed to guide nurses and other health care professionals in decision-making for the well-being of people with HIV/ $\operatorname{AIDS}^{(7-9)}$.

With regard to patients with AIDS in the ICU, who are in more critical condition, knowledge of prognostic factors, mortality and survival are useful for taking therapeutic measures and anticipating health care. Thus, the objective of this study was to analyze the mortality, survival and prognostic factors of patients with AIDS in ICU.

\section{METHODS}

\section{Study Design}

A retrospective cohort study was conducted using the medical records of patients with AIDS admitted to the ICU of the São José Hospital of Infectious Diseases, Fortaleza, Ceará, Brazil.

\section{Sample, Inclusion and Exclusion Criteria}

The sample was calculated with a 95\% confidence level, $80 \%$ power and $50 \%$ increase in mortality risk among people with AIDS and the clinical indicators of interest, giving a sample of 193 patients with AIDS. A quantitative of 5\% was added to the final sample size to minimize the loss of information during the data collection process, leading to a final sample of 202. This type of sample estimate is obtained considering the magnitude of the risk to be identified and does not require data on the size of the population ${ }^{(12)}$. The inclusion criteria were: charts of patients with AIDS of both sexes, over 18 years old, who stayed in the ICU for more than 24 hours. Pregnant women were excluded.

\section{Data Collect}

The data collection took place from January 2017 to January 2019. In the registry of the ICU, we obtained the full name and number of medical records of those patients who met the inclusion criteria. Subsequently, the medical records were requested at the Medical Archive and Statistical Service for analysis. A data collection form validated in previous studies was used and adapted to this study, containing sociodemographic, epidemiological and clinical variables.

The dependent variables or outcomes of interest were mortality and survival time. The independent or predictor variables (prognostic factors) were: age (in years), sex (male, female), skin color (white, brown, black, yellow), education (in years of study), marital status (single, married), occupation, if street dwellers, users of alcohol, illicit drugs (marijuana, cocaine, crack, inhalants), regular follow-up at a health service (yes, no), exposure category (sexual, blood, vertical transmission), sexual orientation (heterosexual, homosexual, bisexual), time on ART (in months), antiretrovirals used and irregular abandonment or use (yes, no), most recent CD4+ T lymphocyte count and viral load, opportunistic infections, comorbidities, cause of admission to the ICU, mechanical ventilation (yes, no), renal replacement therapy (yes, no), sepsis (yes, no), antibiotic therapy (yes, no), vasoactive drugs (yes, no), length of stay in the ICU (in days), destination after discharge, date of death (yes, no). For data not described in the medical record, was placed as uninformed.

\section{Statistical Analysis}

Software R version 3.2 (R Foundation for Statistical Computing, Vienna, Austria) was used for statistical analysis. To determine the prognostic factors of mortality, we compared the groups of survivors and non-survivors. Mean, median and standard deviation (SD) were calculated. In followed by inferential analysis, which included the use of the chi-square test or Fisher's exact test for comparison of categorical variables. The association between exposure and death variables was estimated by the odds ratio and relative risk. The continuous variables were subjected to univariate analysis, where the data were tested for normality and accordingly evaluated using the Student t-test or nonparametric Mann-Whitney test. The level of significance was set at $\mathrm{p}<0.05$ for all the tests used.

A life table based on the Kaplan-Meyer method was constructed to determine patient survival rates. Univariate Cox proportional hazards models were fitted to identify possible prognostic factors for survival. After analysis, a multivariate Cox proportional hazards model was fitted to identify the component variables of the prognostic index for survival. The Cox model fit was analyzed considering the explanatory power of the covariates at the time of occurrence 
of the deaths given by: the coefficient $\mathrm{R}^{2}$; Wald test for regression coefficients (null hypothesis $\beta=0$ ); likelihood ratio test to verify the overall fit of the model; log-rank test to compare the distribution of the occurrence of deaths in each stratum with the distribution that would be expected if the incidence were the same in all strata; and level of agreement that showed the fraction of pairs in the sample, where the observations with longer survival times had more probability predicted by the model.

To verify the assumptions of Cox models, Schoenfeld residuals were analyzed to see if the effect of the covariables was constant during the observation period (proportionality of risks). Plots of the distribution of Schoenfeld residuals with smoothed trend line and confidence intervals were presented. In this analysis, it was expected that the observed oscillations were not significantly different from zero. The rho coefficient with the chi-square test was determined to see if there was linearity between survival time and residual. In this analysis, the null hypothesis tested was that of proportionality of the risks, and it was expected that the applied tests would not show significance. A graph with the Martingale residuals was presented to identify aberrant values that could influence the proportionality of the risks, and these residuals were expected to be between -2 and +2 , which occurred in this study.

\section{Ethical Aspects}

The study was carried out in accordance with Resolution 466/2012 of the National Health Council. The project was approved by the Research Ethics Committee of the São José Hospital in November 2016, under protocol No. 1.832.921. The term of faithful depositary for research with medical records was signed.

\section{RESULTS}

The most patients were male (73.8\%), aged $18-39$ years (60.9\%) (mean \pm SD: $38.2 \pm 10.5$; median: 37.0 ; interquartile range: 15.0 ), with brown skin color (86.1\%), less than eight years of schooling $(78.7 \%)$ (mean $\pm \mathrm{SD}$ : $4.6 \pm 4.9$; median: 4.0; interquartile range: 8.0 ), and single (51.5\%). Some were street dwellers (5.0\%), user drugs and with abandonment or irregular use of antiretrovirals (40.6\%). The majority were in the category of sexual exposure (90.1\%), heterosexual (68.3\%), on ART for less than 12 months (70.2\%) (mean \pm SD: $28.1 \pm 52.7$; median: 0 ; interquartile range: 36.0 ), and without regular follow-up of health care (61.4\%). Before admission to the ICU, the most commonly used antiretrovirals were lamivudine $(112 ; 55.4 \%)$, tenofovir $(80 ; 39.6 \%)$ and efavirenz $(56 ; 27.7 \%)$. In the ICU, these antiretroviral drugs were also more used: lamivudine $(95 ; 47.0 \%)$, tenofovir $(67 ; 33.2 \%)$ and efavirenz $(42 ; 20.8 \%)$. A CD $4+\mathrm{T}$ lymphocyte count less than 350 cells $/ \mathrm{mm}^{3}$ was found in 191 patients $(94.0 \%)$ (mean \pm SD: $86.0 \pm 155.6$; median: 15.0; interquartile range: 87.0 ), and $53(26.2 \%)$ had a viral load greater than 100,000 copies $/ \mathrm{mL}$ (mean \pm SD: $184.2 \pm$ 491.9; median: 882.5; interquartile range: 109.1) (Table 1).
Table 1 - Sociodemographic, epidemiological and clinical characterization of patients with AIDS in the intensive care unit Fortaleza, CE, Brazil, 2017-2019.

\begin{tabular}{|c|c|c|}
\hline Characteristics & $\mathbf{N}$ & $\%$ \\
\hline \multicolumn{3}{|l|}{ Years of study } \\
\hline$\leq 8$ & 159 & 78.7 \\
\hline$>8$ & 43 & 21.3 \\
\hline \multicolumn{3}{|l|}{ Marital status } \\
\hline Single & 133 & 65.9 \\
\hline Married & 67 & 33.2 \\
\hline Uninformed & 2 & 1.0 \\
\hline Street dwellers & 10 & 5.0 \\
\hline Alcohol user & 77 & 38.1 \\
\hline Prisoner & 4 & 2.0 \\
\hline Immigrant & 1 & 0.5 \\
\hline \multicolumn{3}{|l|}{ Illicit drug user } \\
\hline Marijuana & 3 & 1.5 \\
\hline Cocaine & 12 & 5.9 \\
\hline Crack & 26 & 12.9 \\
\hline Inhalants & 2 & 1.0 \\
\hline \multicolumn{3}{|l|}{ Exposure category } \\
\hline Sexual & 182 & 90.1 \\
\hline Blood exposure & 1 & 0.5 \\
\hline Vertical transmission & 4 & 2.0 \\
\hline Uninformed & 15 & 7.4 \\
\hline \multicolumn{3}{|l|}{ Sexual orientation } \\
\hline Heterosexual & 138 & 68.3 \\
\hline Homosexual & 48 & 23.8 \\
\hline Bisexual & 02 & 1.0 \\
\hline Uninformed & 14 & 6.9 \\
\hline \multicolumn{3}{|c|}{ Antiretroviral use time (in months) } \\
\hline$<12$ & 142 & 70.2 \\
\hline $13-36$ & 8 & 4.0 \\
\hline$>36$ & 52 & 25.8 \\
\hline \multicolumn{3}{|c|}{ Abandonment of antiretroviral therapy } \\
\hline No & 120 & 59.4 \\
\hline Yes & 86 & 40.6 \\
\hline \multicolumn{3}{|c|}{ Regular follow-up of health care } \\
\hline No & 124 & 61.4 \\
\hline Yes & 77 & 38.1 \\
\hline Uninformed & 1 & 0.5 \\
\hline \multicolumn{3}{|c|}{ CD4+ T lymphocyte count (cells $/ \mathrm{mm}^{3}$ ) } \\
\hline$\leq 350$ & 191 & 94.0 \\
\hline$>350$ & 12 & 6.0 \\
\hline \multicolumn{3}{|l|}{ Viral load (copies/mL) } \\
\hline$<50$ (undetectable) & 90 & 44.6 \\
\hline $50-100,000$ & 59 & 29.2 \\
\hline$>100,000$ & 53 & 26.2 \\
\hline
\end{tabular}


Table 2 - Bivariate analysis of the factors and pathological conditions associated with death outcome in patients with AIDS in the intensive care unit - Fortaleza, CE, Brazil, 2017-2019.

\begin{tabular}{|c|c|c|c|}
\hline $\begin{array}{l}\text { Factors and } \\
\text { pathological conditions }\end{array}$ & $\begin{array}{l}\text { Odds } \\
\text { ratio }\end{array}$ & $\begin{array}{l}95 \% \text { confidence } \\
\text { interval }\end{array}$ & p value* \\
\hline Mechanical ventilation & 1.917 & $0.418-8.798$ & 0.453 \\
\hline Sepsis & 4.987 & $2.715-9.159$ & $<0.001$ \\
\hline Pulmonary tuberculosis & 1.169 & $0.667-2.049$ & 0.619 \\
\hline $\begin{array}{l}\text { Renal replacement } \\
\text { therapy }\end{array}$ & 2.744 & $1.505-5.000$ & 0.001 \\
\hline Histoplasmosis & 2.045 & $0.978-4.280$ & 0.055 \\
\hline Esophageal candidiasis & 1.006 & $0.502-2.018$ & 0.986 \\
\hline Aspiration pneumonia & 1.182 & $0.555-2.519$ & 0.664 \\
\hline Herpes simplex & 0.919 & $0.420-2.012$ & 0.833 \\
\hline Neurotoxoplasmosis & 0.676 & $0.296-1.544$ & 0.351 \\
\hline $\begin{array}{l}\text { Pneumocystis jiroveci } \\
\text { pneumonia }\end{array}$ & 1.122 & $0.461-2.728$ & 0.800 \\
\hline Cytomegalovirus & 0.943 & $0.378-2.352$ & 0.900 \\
\hline Cryptococcosis & 0.599 & $0.208-1.721$ & 0.337 \\
\hline Isosporidiosis & 0.820 & $0.265-2.533$ & 0.730 \\
\hline Herpes zoster & 0.554 & $0.144-2.129$ & 0.384 \\
\hline Hepatitis B & 0.171 & $0.019-1.558$ & 0.163 \\
\hline Mycobacteriosis & 2.912 & $0.320-26.534$ & 0.321 \\
\hline
\end{tabular}

The most common opportunistic diseases were pulmonary tuberculosis $(30 ; 14.9 \%)$, esophageal candidiasis (41; 20.3\%), neurotoxoplasmosis $(26 ; 12.9 \%)$ and Pneumocystis jiroveci pneumonia $(23 ; 11.4 \%)$. The most common comorbidities were hypertension $(28 ; 13.9 \%)$, dyslipidemia $(51 ; 25.2 \%)$ and nephropathy $(79 ; 39.1 \%)$. Of the 202 patients, 84 were discharged to the ward (41.5\%) and 118 (58.5\%) died in the ICU. In the bivariate analysis, the factors possibly associated with death outcome were sepsis $(\mathrm{p}<0.001)$ and renal replacement therapy $(\mathrm{p}=0.001)$ (Table 2$)$.

Regarding survival, it was observed that the greater the ICU stay, the greater the risk of mortality. Overall survival was $41.6 \%$ and the median risk of death occurred between the 15th and 19th day of ICU stay. The mean length of stay was 11.9 days (SD: 10.5 ; median: 8.5 ; interquartile range: 14; $\mathrm{p}<0.001$ ) (Table 3).

The Kaplan-Meier curves showed that survival occurred between the 10th and 15th days of hospitalization (median: 15 days; $95 \%$ confidence interval $=11-19)$. The last mortality records were on the 45 th day of ICU stay (Figure 1).

The reasons for ICU admission were respiratory failure (194; 96.0\%), sepsis (121; 59.9\%), neurological changes (110; $54.5 \%)$ and renal failure $(65 ; 32.2 \%)$. The main causes of hospitalization related to AIDS were toxoplasmosis (41; $20.3 \%)$, fungal disease $(26 ; 12.9 \%)$, bacterial pneumonia $(23 ; 11.4 \%)$ and mycobacterial infection $(22 ; 10.9 \%)$. NonAIDS-related causes included aspiration pneumonia (34, $16.6 \%)$ and neurological disorders $(13 ; 15.8 \%)$. The most prevalent intensive therapy was mechanical ventilation
$(195 ; 96.5 \%)$, use of vasoactive drugs $(186 ; 92.1 \%)$ and renal replacement therapy $(83 ; 41.1 \%)$.

The Cox model showed adequate adjustment as observed by the Wald index and likelihood ratio. The log-rank test showed that the occurrence of deaths showed a statistically significant difference over time. The percentage of explanation of the variation of deaths by covariates was also about $70 \%$ (0.694 for a maximum of 0.994) with high agreement of the values predicted by the model and the survival observed in the sample $(0.891 ; 95 \%$ confidence interval: $0.823-0.954)$. Nine variables were included in the model, two of which were associated with a reduction in the risk of death in the ICU, which were the presence of neurological disorder and esophageal candidiasis on admission. On the other hand, prolonged ICU stay, presence of sepsis on admission, neurological disorders on admission, presence of pressure injury, increased viral load, use of efavirenz and category of sexual exposure to HIV were associated with increased risk of death (Table 4).

\section{DISCUSSION}

The majority of the patients were male, representing young adults, corroborating other studies ${ }^{(7,9)}$. Brown skin color was prevalent, in disagreement with other studies reporting that HIV infection affects blacks more ${ }^{(13-14)}$. A worrisome finding was the low educational level of the patients, because lower levels of schooling have a negative influence on ART adherence ${ }^{(15)}$, increasing opportunistic diseases and hospitalizations. On the other hand, higher schooling is related to safe sex practices and regular checkups at health centers ${ }^{(16)}$.

There were many who drank alcoholic beverages and used illicit drugs. Alcohol abuse can cause hepatotoxicity and worsening of coinfections, such as hepatitis $\mathrm{B}^{(17)}$. In addition, drug use is common in patients with HIV, which is associated with situations of vulnerability, increased virus transmission, abandonment of ART, higher incidence of hospitalization and increased of morbidity and mortality ${ }^{(18)}$. Most of the patients were from the category of sexual and heterosexual exposure, similar to that found in another study, differing from the beginning of the epidemic, where homosexuals were the most affected ${ }^{(19)}$.

A general health profile of the patients was that they had used antiretrovirals for less than a year, with cases of abandonment or irregular use of ART, besides lack of regular monitoring at health care services, low CD4+ T lymphocyte count and high viral load. Currently, the only treatment for people with HIV is ART, and adequate adherence is important. As in the present work, others have shown that many patients have a late diagnosis of HIV infection, initiate ART already with some opportunistic disease or comorbidity present, or live under conditions of vulnerability, which negatively affect adherence to treatment ${ }^{(20-21)}$. In relation to CD4+ T lymphocytes and viral load, one study showed that the monitoring of these two parameters provided useful information for improving life expectancy, but that the monitoring of viral load was a better predictor of HIV/ AIDS progression ${ }^{(22)}$. 
Table 3 - Analysis of hospitalization time, mortality and survival of patients with AIDS in the intensive care unit - Fortaleza, CE, Brazil, 2017-2019.

\begin{tabular}{|c|c|c|c|c|c|c|}
\hline $\begin{array}{l}\text { ICU* stay } \\
\text { (days) }\end{array}$ & $\begin{array}{l}\text { Death event in the sample } \\
(N=118)\end{array}$ & $\begin{array}{c}\text { Number of events } \\
\text { (deaths) }\end{array}$ & Survival & Standard error & $95 \% \mathrm{Cl}^{* *}$ Lower & $95 \% \mathrm{Cl}$ Upper \\
\hline 0 & 202 & 2 & 0.990 & 0.007 & 0.977 & 1.000 \\
\hline 1 & 200 & 7 & 0.955 & 0.015 & 0.927 & 0.984 \\
\hline 2 & 188 & 10 & 0.905 & 0.021 & 0.865 & 0.946 \\
\hline 3 & 176 & 17 & 0.817 & 0.028 & 0.765 & 0.873 \\
\hline 4 & 150 & 10 & 0.763 & 0.031 & 0.705 & 0.825 \\
\hline 5 & 138 & 5 & 0.735 & 0.032 & 0.675 & 0.800 \\
\hline 6 & 127 & 3 & 0.718 & 0.033 & 0.656 & 0.785 \\
\hline 7 & 119 & 8 & 0.670 & 0.035 & 0.605 & 0.741 \\
\hline 8 & 106 & 3 & 0.651 & 0.035 & 0.585 & 0.724 \\
\hline 9 & 99 & 2 & 0.637 & 0.036 & 0.571 & 0.712 \\
\hline 10 & 96 & 4 & 0.611 & 0.037 & 0.543 & 0.687 \\
\hline 11 & 88 & 6 & 0.569 & 0.038 & 0.500 & 0.649 \\
\hline 12 & 81 & 3 & 0.548 & 0.038 & 0.478 & 0.629 \\
\hline 13 & 76 & 3 & 0.526 & 0.039 & 0.456 & 0.609 \\
\hline 14 & 68 & 2 & 0.511 & 0.039 & 0.440 & 0.594 \\
\hline 15 & 64 & 2 & 0.495 & 0.040 & 0.423 & 0.579 \\
\hline 16 & 59 & 3 & 0.470 & 0.040 & 0.397 & 0.556 \\
\hline 17 & 55 & 2 & 0.453 & 0.041 & 0.380 & 0.540 \\
\hline 18 & 48 & 3 & 0.424 & 0.041 & 0.351 & 0.513 \\
\hline 19 & 43 & 3 & 0.395 & 0.042 & 0.321 & 0.486 \\
\hline 21 & 33 & 2 & 0.371 & 0.042 & 0.296 & 0.464 \\
\hline 22 & 31 & 1 & 0.359 & 0.043 & 0.284 & 0.453 \\
\hline 23 & 28 & 3 & 0.321 & 0.044 & 0.246 & 0.418 \\
\hline 24 & 24 & 4 & 0.267 & 0.044 & 0.194 & 0.368 \\
\hline 27 & 20 & 1 & 0.254 & 0.044 & 0.181 & 0.355 \\
\hline 28 & 17 & 2 & 0.224 & 0.043 & 0.153 & 0.327 \\
\hline 29 & 14 & 1 & 0.208 & 0.043 & 0.139 & 0.312 \\
\hline 30 & 13 & 3 & 0.160 & 0.041 & 0.097 & 0.264 \\
\hline 33 & 9 & 1 & 0.142 & 0.040 & 0.082 & 0.247 \\
\hline 44 & 4 & 1 & 0.107 & 0.043 & 0.048 & 0.235 \\
\hline 57 & 1 & 1 & 0 & - & - & - \\
\hline
\end{tabular}

*Intensive Care Unit; **Confidence Interval.

The most common opportunistic diseases were pulmonary tuberculosis, neurotoxoplasmosis, esophageal candidiasis and Pneumocystys jiroveci pneumonia, in agreement with other studies $^{(23-24)}$. As for the reasons that led patients with AIDS to be admitted to the ICU, respiratory failure, sepsis, neurological changes and renal failure were the most noteworthy. The chance of a person with HIV to develop tuberculosis is 30 times higher when compared to people without the virus, because in these patients there is a serious progression of the disease, and ICU admission is often necessary ${ }^{(25)}$. Acute respiratory failure caused by opportunistic infections accounts for 25 to $50 \%$ of ICU admissions of patients with
AIDS $^{(26)}$, being the most common cause of hospitalization ${ }^{(9)}$, with Pneumocystys jiroveci pneumonia as the main cause ${ }^{(23,27)}$. However, severe sepsis is the most important risk factor for mortality in patients with $\operatorname{AIDS}^{(7)}$.

In a study conducted in Russia, the most frequently observed opportunistic infections were cytomegalovirus, pneumocystis pneumonia, esophageal candidiasis, tuberculosis and cerebral toxoplasmosis. The non-AIDS-related causes were chronic hepatitis $\mathrm{C}$ and the mixed form of chronic hepatitis with complications of cirrhosis ${ }^{(23)}$. Opportunistic infections are still the main cause of hospitalization of people with AIDS in the ICU, mainly in low- and middle-income 


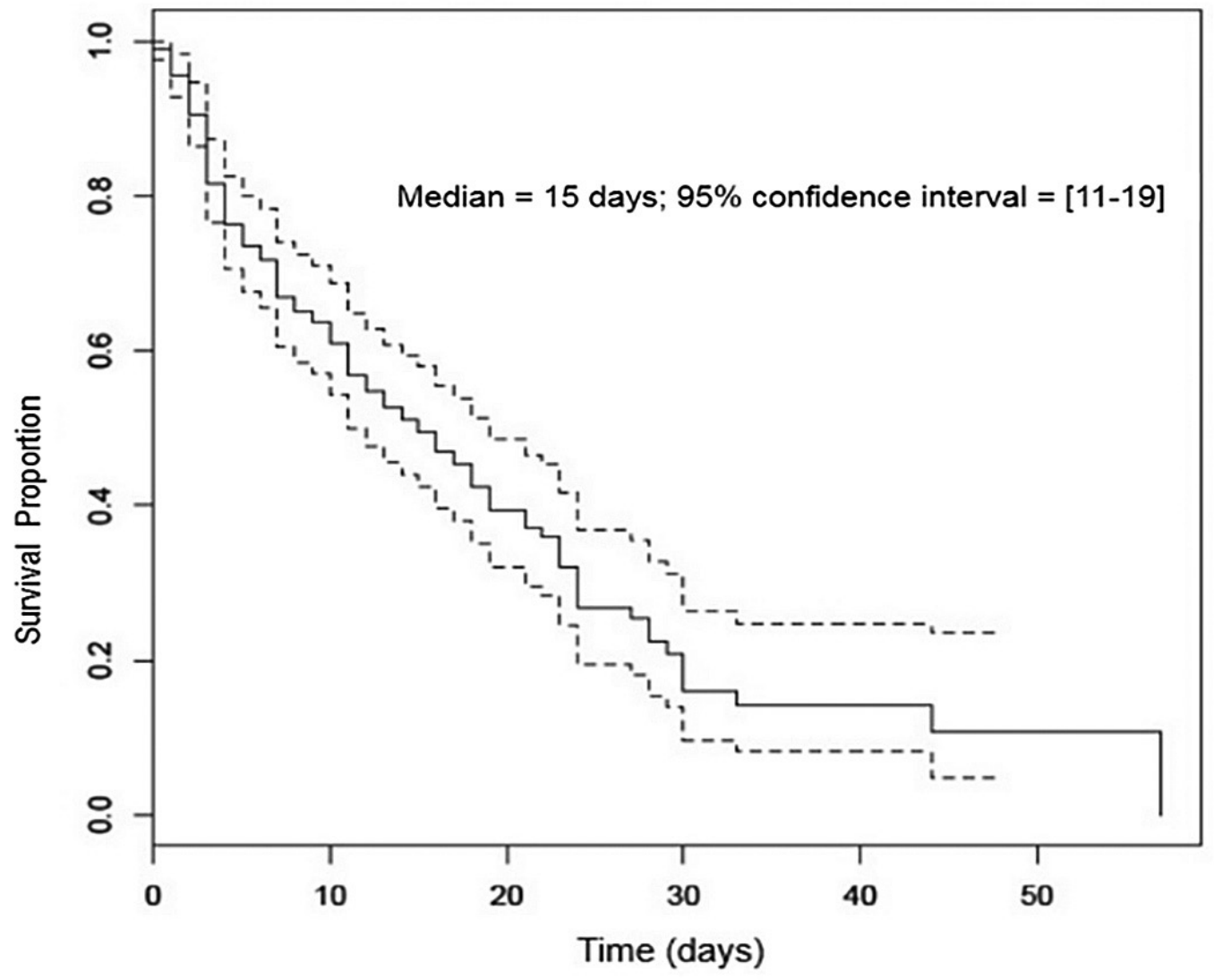

Figure 1 - Kaplan-Meier curves of cumulative probability of survival of people with AIDS in intensive care unit - Fortaleza, CE, Brazil, 2017-2019.

Table 4 - Multivariate Cox model for the prognosis of AIDS patients in intensive care unit - Fortaleza, CE, Brazil, $2017-2019$.

\begin{tabular}{|c|c|c|c|c|c|}
\hline Variable & Coefficient & $\mathrm{HR}^{* *}$ & $95 \% \mathrm{Cl}^{+}$ & z & p value ${ }^{\ddagger}$ \\
\hline ICU* stay (days) & 0.28 & 1.32 & $1.25-1.38$ & 10.71 & $<0.001$ \\
\hline Sepsis on admission & 1.43 & 4.18 & $2.14-8.13$ & 4.21 & $<0.001$ \\
\hline \multicolumn{6}{|l|}{ Exposure category } \\
\hline Sexual exposure & 1.98 & 7.21 & $2.00-25.91$ & 3.02 & 0.002 \\
\hline Vertical transmission & 1.71 & 5.52 & $0.43-71.14$ & 1.31 & 0.191 \\
\hline Blood exposure & 3.85 & 46.78 & $4.13-529.52$ & 3.11 & 0.002 \\
\hline Pressure injury & 0.70 & 2.01 & $1.04-3.90$ & 2.08 & 0.038 \\
\hline Neurological disorder & 1.32 & 3.74 & $1.33-10.56$ & 2.49 & 0.013 \\
\hline Neurological disorder on admission & -1.11 & 0.33 & $0.11-0.97$ & -2.02 & 0.043 \\
\hline Esophageal candidiasis & -1.12 & 0.33 & $0.16-0.68$ & -2.99 & 0.003 \\
\hline Viral load & 0.00 & 1.00 & $1.00-1.00$ & 3.23 & 0.001 \\
\hline Use of efavirenz & 0.54 & 1.72 & $1.06-2.82$ & 2.18 & 0.030 \\
\hline \multicolumn{6}{|l|}{ Adjustment statistics } \\
\hline Agreement & 0.891 & \multicolumn{4}{|c|}{ Confidence interval 95\%: 0.823-0.954 } \\
\hline $\mathrm{R}^{2}$ & 0.694 & \multicolumn{4}{|c|}{ Maximum possible: 0.994} \\
\hline Likelihood ratio test & & & 239.5 & $d f^{\S}: 11$ & $P<0.001$ \\
\hline Wald test & & & 148.8 & df: 11 & $P<0.001$ \\
\hline Test score (log-rank) & & & 168.6 & df: 11 & $P<0.001$ \\
\hline
\end{tabular}

*Intensive care unit; ${ }^{* *}$ Hazard ratio; ${ }^{+}$Confidence interval; ${ }^{\star} \mathrm{Chi}$-square test; ${ }^{\circledR}$ Degrees of freedom. 
countries, with non-adherence to ART or without access to health care services. It has also been found that conditions not associated with HIV have gained importance as causes of hospitalization $^{(28)}$.

In this study, the most common comorbidities were arterial hypertension, dyslipidemia and nephropathy, where nowadays, people with AIDS are also admitted to the ICU for conditions associated with aging, chronic health conditions and trauma from accidents and violence ${ }^{(10)}$. It is not known for sure whether the development of chronic diseases in people living with HIV is related to increased survival due to antiretrovirals, which causes these individuals to reach aging; whether it is related to HIV infection itself; whether it can be attributed to ART, due to side effects or long-term adverse events; or whether all of these factors contribute synergistically to the occurrence of disease.

Among intensive care and treatment for specific conditions, mechanical ventilation, use of vasoactive drugs, renal replacement therapy and treatment for neurocryptococcosis stood out the most. It has been pointed out that mechanical ventilation and other invasive interventions may be related to the occurrence of infection and increased length of stay in the ICU, indicating a worse prognosis for the patient ${ }^{(29)}$.

Before and during ICU admission, the most used antiretrovirals were lamivudine, tenofovir, and efavirenz. Due to the complexity of ART in the ICU, nurses and other professionals of the health team should consider the risks of drug interaction and recognize the challenges associated with the administration of antiretrovirals, especially the risk of resistance, patient safety and quality of care provided ${ }^{(10)}$. This study supports the initiation and maintenance of ART in patients with AIDS in the ICU, as there is a tendency for better results, despite the drug interactions and toxic effects of antiretrovirals ${ }^{(28)}$.

On average, $58.5 \%$ of the patients died in the ICU, a rate similar to that found in other studies, with sepsis and renal replacement therapy being the factors associated with death outcome and with worse prognosis, in agreement with other studies ${ }^{(8,27)}$. These findings showed a high mortality in people with AIDS in the ICU. Most of them were admitted because of opportunistic infections, and when compared to the seronegative individuals in this environment, more people with AIDS evolved to sepsis, with a higher mortality rate. Usually, sepsis occurs in these patients from the respiratory focus ${ }^{(27)}$.

The mean length of stay in the ICU was 11.9 days, and the longer the length of stay, the shorter the survival. In another study conducted in Brazil, the median length of stay for people with AIDS in the ICU was 21 days ${ }^{(21)}$. ART is the most important intervention to reduce the mortality of people with HIV, as well as adequate access of patients to health services. It is also observed that admissions and deaths of people with AIDS in the ICU have been decreasing over time due to $\operatorname{ART}^{(7)}$.

Esophageal candidiasis and neurological disturbance on admission were associated with reduced risk of death in the ICU. In this study, the mathematical model used showed a protective association, however, no other studies were identified to confirm these findings. The literature shows that fungal infections are rarer compared to bacterial infections, but are increasing in the ICU, and immunocompromised individuals are at increased risk ${ }^{(17,23)}$. Fatigue and fever are common symptoms, and the nurses who work in the ICU to be vigilant in identifying patients at risk and to promote timely and appropriate treatments for fungal infections. It should be emphasized the importance of controlling glucose levels, reduction of invasive procedures and unnecessary use of antibiotics $^{(17)}$.

Sepsis at ICU admission, prolonged intensive care, pressure injury, neurological disorders in the ICU, high viral load, use of efavirenz and being from the category of sexual exposure to HIV were associated with an increased risk of death. The sepsis can lead to dysfunction or failure of multiple organs, where is the main cause of death of people with AIDS in the ICU, and one of the leading causes of late hospital mortality ${ }^{(7,17)}$.

The patients who are hospitalized longer in the ICU are those in more serious condition and exposed to invasive procedures. A study showed that mechanical ventilation, tracheostomy and reintubation are significantly correlated with prolonged hospitalization and higher mortality, a prolonged time is considered a period longer than seven days in the $\mathrm{ICU}^{(29)}$. Probes, drains and catheters, pressure lesions and adverse events are also related to a higher occurrence of death ${ }^{(8-10,17-18)}$. In relation to pressure injuries, the probability of occurrence increases 3.5 times in patients with mechanical ventilation, 7.8 times in those under palliative care, 2.3 times in the 60-84 age group, and 10\% each day of hospitalization ${ }^{(30)}$.

In this study, the efavirenz use was associated with an increased risk of death. It is important to make it clear that we are not claiming that this medication can cause death, including this is an antiretroviral widely used by people with HIV. However, studies shows some aspects that may be associated with this finding. The central nervous system toxicities from regimens containing efavirenz are the main reasons for non-adherence, switch and discontinuation of ART $^{(5,28)}$. About $52.8 \%$ of participants experienced adverse events. Vivid dreams, confusion, insomnia and somnolence were the most frequently reported adverse events. Most adverse events occurred in the first year of treatment initiation and resolved within 1-4 weeks. Age, economic status, CD4+ T lymphocyte count, disease stage, presence of comorbidities and concurrent use of other medication had a significant association with the occurrence of adverse events of the central nervous system. Health-care providers should give attention to patients on efavirenz therapy to monitor for adverse events, especially for patients who have low CD4 count, advanced disease, comorbidities, low income and are older in age ${ }^{(5)}$.

Finally, despite the free and sustainable availability of ART in Brazil, hospitalizations of patients with AIDS in the ICU occur mainly due to the conditions of vulnerability in which these patients live, resulting in nonadherence to ART or not getting chemoprophylaxis for opportunistic 
diseases. Vulnerable situations can include the poverty, low education level, stigma, lack of social support and access to health services, to be homeless and drug user ${ }^{(19,23,28)}$. Thus, hospitalizations in the ICU generate premature deaths, which occur even after discharge of the patients.

The data in this study represents an innovation, because there isn't much research in Brazil about people with AIDS in the ICU, especially considering health services of reference in the care of patients with HIV in the poorest regions of the country, where we know that this has an impact on the way these patients live and lead their disease. The findings contribute to the advancement of knowledge in the area of health and nursing, as it points out the factors most associated with complications and mortality of AIDS patients in the ICU, which is important to speed up care and procedures.

A limitation of the study was that there was no control group without AIDS to compare the results, and also the lack of some data in the medical records. Therefore, further studies are needed to examine mortality, survival and prognostic factors in patients with AIDS compared to patients without the disease.

\section{CONCLUSION}

The majority of AIDS patients in the ICU were male, drug users, without regular health care, nonadherent to ART, with low CD4+ T lymphocyte count and high viral load. They were hospitalized for the consequences of opportunistic diseases, especially pulmonary tuberculosis and esophageal candidiasis. The causes of hospitalization were respiratory insufficiency, sepsis, neurological changes and renal failure. The mean time of hospitalization was 11.9 days, and the number of deaths was higher than that of survivors, with sepsis and renal replacement therapy being associated with death. In addition, patients with sepsis on admission, pressure injury, efavirenz use, sexual exposure to HIV, high viral load and prolonged hospitalization had a higher risk of death.

\section{RESUMO}

Objetivo: Analisar a mortalidade, sobrevida e fatores prognósticos de pacientes com aids em Unidade de Terapia Intensiva (UTI). Método: Estudo de coorte retrospectivo, com amostra de 202 pessoas com aids em UTI, cujas características sociodemográficas, epidemiológicas e clínicas foram obtidas em prontuários e avaliadas. Resultados: A maioria dos pacientes era do sexo masculino (73,8\%) e usuária de drogas (59,4\%), sem acompanhamento regular de saúde (61,4\%), não aderente aos antirretrovirais (40,6\%), com baixa contagem de linfócitos T CD4+ (94,0\%) e carga viral elevada (44,6\%). As principais causas de internação foram sepse e insuficiência respiratória e renal. O tempo médio de internação foi de 11,9 dias ( $p=0,0001)$, com sobrevida de 41,6\%; 58,5\% foram a óbito na UTI. Sepse na admissão ( $\mathrm{p}<0,001)$, lesão por pressão $(\mathrm{p}=0,038)$, exposição sexual $(\mathrm{p}=0,002)$, carga viral elevada ( $\mathrm{p}=0,00001)$ e hospitalização prolongada $(\mathrm{p}<0,001)$ aumentaram o risco de morte. Conclusão: A maioria dos pacientes não tinha acompanhamento regular de saúde, era usuária de drogas e apresentava baixa contagem de linfócitos T CD4+ e alta carga viral. A mortalidade foi elevada, indicando que a adesão antirretroviral é essencial para reduzir a resistência viral, doenças oportunistas e mortalidade.

\section{DESCRITORES}

Síndrome de Imunodeficiência Adquirida; Mortalidade; Sobrevida; Unidades de Terapia Intensiva.

\section{RESUMEN}

Objetivo: Analizar la mortalidad, la supervivencia y los factores pronósticos de los pacientes con SIDA en la Unidad de Cuidados Intensivos (UCI). Método: Estudio de cohorte retrospectivo con una muestra de 202 personas con SIDA en la UCI, cuyas características sociodemográficas, epidemiológicas y clínicas fueron obtenidas de las historias clínicas y evaluadas. Resultados: La mayoría de los pacientes eran del sexo masculino $(73,8 \%)$ y consumidores de drogas $(59,4 \%)$, sin seguimiento sanitario regular $(61,4 \%)$, no adherentes a los antirretrovirales (40,6\%), con bajo recuento de linfocitos T CD4+ (94,0\%) y carga viral elevada (44,6\%). Las principales causas de hospitalización fueron la sepsis y la insuficiencia respiratoria y renal. La duración media de la hospitalización fue de 11,9 días ( $p=0,0001)$, con una supervivencia del 41,6\%; el 58,5\% falleció en la UCI. La sepsis al ingreso ( $\mathrm{p}<0,001)$, las lesiones por presión $(\mathrm{p}=0,038)$, la exposición sexual $(\mathrm{p}=0,002)$, la carga viral elevada $(\mathrm{p}=0,00001)$ y la hospitalización prolongada $(\mathrm{p}<0,001)$ aumentaron el riesgo de muerte. Conclusión: La mayoría de los pacientes no tenían un seguimiento sanitario regular, eran consumidores de drogas y tenían recuentos bajos de linfocitos T CD4+ y una carga viral elevada. La mortalidad fue elevada, lo que indica que la adherencia a los antirretrovirales es esencial para reducir la resistencia viral, las enfermedades oportunistas y la mortalidad.

\section{DESCRIPTORES}

Síndrome de Inmunodeficiencia Adquirida; Mortalidad; Sobrevida; Unidades de Cuidados Intensivos.

\section{REFERENCES}

1. Sauter D, Kirchhoff F. Key viral adaptations preceding the AIDS pandemic. Cell Host Microbe. 2019;25(1):27-38. DOI: https://dx.doi. org/10.1016/j.chom.2018.12.002.

2. Sangaramoorthy T. Chronicity, crisis, and the 'end of AIDS'. Glob Public Health. 2018;13(8):982-96. DOI: https://dx.doi.org/10.1080/1 7441692.2018.1423701.

3. Tegegne AS, Ndlovu P, Zewotir T. Factors affecting first month adherence due to antiretroviral therapy among HIV-positive adults at felege hiwot teaching and specialized hospital, north-western Ethiopia; a prospective study. BMC Infect Dis. 2018;18:83. DOI: https://dx.doi. org/10.1186/s12879-018-2977-0.

4. Erlandson KM, Li X, Abraham AG, Margolick JB, Lake JE, Palella Jr FJ, et al. Long-term impact of HIV wasting on physical function. AIDS. 2016;30(3):445-54. DOI: https://dx.doi.org/10.1097/QAD.0000000000000932. 
5. Muche EA, Kiflu M, Ayalew MB. Patient reported central nervous system adverse events of efavirenz-based antiretroviral therapy in people living with HIV in Northwest Ethiopia. HIV/AIDS - Research and Palliative Care. 2020;12:601-609. DOI: https://dx.doi.org/10.2147/HIV. S276111.

6. Yaya S, Bishwajit G, Danhoundo G, Shah V, Ekholuenetale M. Trends and determinants of HIV/AIDS knowledge among women in Bangladesh. BMC Public Health. 2016;16:812. DOI: https://dx.doi.org/10.1186/s12889-016-3512-0.

7. Łojko P, Piechota M. Reasons for hospitalisation of HIV-infected patients in ICUs - a single-centre observational study. Anaesthesiol Intensive Ther. 2015;47(3):200-3. DOI: https://dx.doi.org/10.5603/AIT.2015.0032.

8. Huson MA, Bakhshi-Raiez F, Grobusch MP, Jonge E, Keizer NF, Poll TVD. Characteristics and outcome of patients with AIDS in dutch ICUs between 1997 and 2014. Crit Care Med. 2016;44(2):291-9. DOI: https://dx.doi.org/ 10.1097/CCM.0000000000001385.

9. Palacios R, Hidalgo A, Reina C, Torre M, Márquez M, Santos J. Effect of antiretroviral therapy on admissions of HIV-infected patients to an intensive care unit. HIV Med. 2006;7(3):193-6. DOI: https://dx.doi.org/10.1111/j.1468-1293.2006.00353.x.

10. DeFreitas AA, D'Souza TLM, Lazaro GJ, Windes EM, Johnson MD, Relt MV. Pharmacological considerations in human immunodeficiency virus-infected adults in the intensive care unit. Crit Care Nurse. 2013;33(2):46-56. DOI: https://dx.doi.org/10.4037/ccn2013854.

11. Joint United Nations Programme on HIV/AIDS [Internet]. Genebra: UNAIDS; 2014 [cited 2021 Jan 3]. 90-90-90 An ambitious treatment target to help end the AIDS epidemic, 2014. Available from: http://www.unaids.org/sites/default/files/media_asset/90-90-90_en.pdf.

12. Belle G, Fisher LD, Heagerty PJ, Lumley T. Biostatistics: A methodology for the health sciences. Hoboken: Wiley-Interscience; 2004.

13. Marks SM, Katz DJ, Davidow AL, Pagaoa MA, Teeter LD, Graviss EA. The impact of HIV infection on TB disparities among US-born black and white tuberculosis patients in the United States. J Public Health Manag Pract. 2020;26(5):E5-E12. DOI: https://dx.doi.org/10.1097/ PHH.0000000000000949.

14. Becasen JS, Denard CL, Mullins MM, Higa DH, Sipe TA. Estimating the prevalence of HIV and sexual behaviors among the US transgender population: a systematic review and meta-analysis, 2006-2017. Am J Public Health. 2019;109(1):e1. DOI: https://dx.doi.org/10.2105/ AJPH.2018.304727.

15. Pires PN, Marega A, Creagh JM. Adesão à terapia antirretroviral em pacientes infectados pelo VIH nos cuidados de saúde primários em Nampula, Mozambique. Rev Port Med Geral Fam. 2017;33(1):30-40. DOI: https://dx.doi.org/10.32385/rpmgf.v33i1.12021.

16. Bunyasi EW, Coetzee DJ. Relationship between socioeconomic status and HIV infection: findings from a survey in the Free State and Western Cape Provinces of South Africa. BMJ Open. 2017;7:e016232. DOI: https://dx.doi.org/10.1136/bmjopen-2017-016232.

17. Verdugo F, Pinto F, Charpentier P, Mühlenbrock CV, Soto A, Dabanch J, et al. HIV/AIDS patients in a critical care unit: the experience of a general hospital in a developing country. Rev Chilena de Infectol. 2015;32(3):294-303. DOI: https://dx.doi.org/10.4067/S071610182015000400007.

18. Yassue AK, Oliveira CA, Oliveira CS, Goulart LT, Oikawa KH, Jorge AC, et al. AIDS in intensive care unit patients: epidemiology and outcomes. J AIDS Clin Res. 2017;8(5):1000691. DOI: https://dx.doi.org/ 10.4172/2155-6113.1000691.

19. Xiao J, Zhang W, Huang Y, Tian Y, Su W, Li Y, et al. Etiology and outcomes for patients infected with HIV in intensive care units in a tertiary care hospital in China. J Med Virol. 2015;87(3):366-74. DOI: https://dx.doi.org/10.1002/jmv.24063.

20. Mkoko P, Raine RI. HIV-positive patients in the intensive care unit: a retrospective audit. S Afr Med J. 2017;107(10):877-81. DOI: https:// dx.doi.org/10.7196/SAMJ.2017.v107i10.12298.

21. Souza PN, Miranda EJP, Cruz R, Forte DN. Palliative care for patients with HIV/AIDS admitted to intensive care units. Rev Bras Ter Intensiva. 2016;28(3):301-9. DOI: https://dx.doi.org/10.5935/0103-507X.20160054.

22. Shoko C, Chikobvu D. A superiority of viral load over CD4 cell count when predicting mortality in HIV patients on therapy. BMC Infect Dis. 2019;19:169. DOI: https://dx.doi.org/10.1186/s12879-019-3781-1.

23. Kozhevnikova GM, Voznesenskiy SL, Ermak TN, Petrova EV, Golub VP, Barysheva IV. Opportunistic diseases in patients with HIV infection in the intensive care unit. Ter Arkh. 2018;90(11):13-7. DOI: https://dx.doi.org/10.26442/terarkh2018901113-17.

24. Barreneche MFA, Castro CAR, Botero AH, Franco JPV, Romero IMT, Carvajal LR, et al. Hospitalization causes and outcomes in HIV patients in the late antiretroviral era in Colombia. AIDS Res Ther. 2017;14(1):60. DOI: https://dx.doi.org/10.1186/s12981-017-0186-3.

25. Ferreira MD, Neves CP, Souza AB, Beraldi-Magalhães F, Migliori GB, Kritski AL, et al. Predictors of mortality among intensive care unit patients coinfected with tuberculosis and HIV. J Bras Pneumol. 2018;44(2):118-24. DOI: https://dx.doi.org/10.1590/s180637562017000000316 .

26. Kar SK, Chakraborty B, Ghosh S, Sarkar M, Ray R. HIV in intensive care unit: concerns and constraints of intensivists. Transl Biom. 2015;6(4). DOI: https://dx.doi.org/10.21767/2172-0479.100028.

27. Kwizera A, Nabukenya M, Peter A, Semogerere L, Ayebale E, Katabira C, et al. Clinical characteristics and short-term outcomes of HIV patients admitted to an African intensive care unit. Crit Care Res Pract. 2016;2016:2610873. DOI: https://dx.doi.org/10.1155/2016/2610873.

28. Andrade HB, Shinotsuka CR, Silva IRF, Domini CS, Li HY, Carvalho FB. Highly active antiretroviral therapy for critically ill HIV patients: a systematic review and meta-analysis. PLoS One. 2017;12(10):e0186968. DOI: https://dx.doi.org/10.1371/journal.pone.0186968.

29. Oliveira ABF, Dias OM, Mello MM, Araújo S, Dragosavac D, Nucci A, et al. Factors associated with increased mortality and prolonged length of stay in an adult intensive care unit. Rev Bras Ter Intensiva. 2010;22(3):250-6. DOI: https://dx.doi.org/10.1590/S0103$507 \times 2010000300006$

30. Strazzieri-Pulido KC, González CVS, Nogueira PC, Padilha KG, Santos VLCG. Pressure injuries in critical patients: incidence, patientassociated factors, and nursing workload. J Nurs Manag. 2019;27(2):301-10. DOI: https://dx.doi.org/10.1111/jonm.12671. 